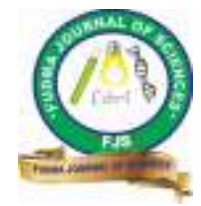

FUDMA Journal of Sciences (FJS)

ISSN online: $2616-1370$

ISSN print: 2645 - 2944

Vol. 4 No. 3, September, 2020, pp $197-200$

DOI: https://doi.org/10.33003/fjs-2020-0403-127

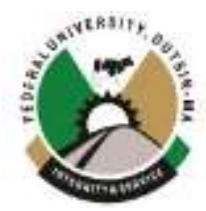

\title{
DISTRIBUTION OF ABO/RHESUS BLOOD GROUPS AMONG HEPATITIS B VIRUS (HBV) POSITIVE PATIENTS IN LAGOS, SOUTH-WESTERN, NIGERIA
}

\author{
${ }^{* 1}$ Oladele, E. O., ${ }^{2}$ Yahaya, T. O., ${ }^{1}$ Adewumi, O. O., ${ }^{3}$ David, B. and ${ }^{1}$ Oladipo, A. J. \\ ${ }^{1}$ Biology Unit, Distance Learning Institute, University of Lagos, Nigeria \\ ${ }^{2}$ Department of Biology, Federal University Birnin Kebbi, Kebbi State, Nigeria \\ ${ }^{3}$ Department of Biology, Faculty of Science, National Open University of Nigeria, Lagos, Nigeria \\ *Correspondence Author: E-mail: eoladele@unilag.edu.ng, esteroladele1@,gmail.com
}

\begin{abstract}
The study aims to determine the distribution of the $\mathrm{ABO} /$ Rhesus Blood Groups among Hepatitis $\mathrm{B}$ virus (HBV) positive patients in Lagos State. Copies of structured questionnaires were distributed to $162 \mathrm{HBV}$ patients that visited selected health facilities within 6 months in the city. After obtaining relevant information, whole blood samples were collected from each participant in an EDTA bottle. Thereafter, the ABO blood group types (A, B, AB, and $\mathrm{O}$ ) as well as Rhesus blood groups were determined using standard protocols. Results showed that $48.1 \%$ of the participants had type O blood group, followed by type A (26.5\%), type B (24.7\%), and type $\mathrm{AB}(0.6 \%)$. Moreover, $94.4 \%$ of the participants were $\mathrm{Rh}+$. The study showed that HBV was more prevalent among participants with type O blood group (48.1\%) with rhesus positivity of $94.4 \%$, compared to other blood group types. This indicates that type $\mathrm{O}$ individuals in the city could be more susceptible to HBV infection. There should be public awareness on the association between $\mathrm{ABO} / \mathrm{Rh}$ blood groups and the prevalence of HBV infection in the state.
\end{abstract}

Keywords: Hepatitis B virus, ABO blood groups, rhesus factor, prevalence.

\section{INTRODUCTION}

Hepatitis B virus (HBV) belongs to the family of Hepadnaviridae, comprising of small enveloped viruses (WHO, 2018). Hepadnaviridae causes acute and insistent infections with viremia and antigenemia. Strong hepatotropism combined with relatively strict species specificity are further hallmarks of this viral family. The hepatitis B virus has the ability to survive outside the body of a living organism for at least 7 days (Pirtle and Beran, 1991). During this period, the virus has the potential to cause infection if it enters the body of a person who has not been vaccinated. The incubation period of the hepatitis $\mathrm{B}$ virus is 75 days on average, but varies from 30 to 180 days (WHO, 2018). The virus may be detected within 30 to 60 days after infection, if it persists, it can develop into chronic hepatitis B (WHO, 2018).

In areas where the infection is prevalent, hepatitis B is widely spread from mother to child at birth (perinatal transmission), or through horizontal transmission (exposure to infected blood), particularly from an infected child to an uninfected child during the first 5 years of life (WHO, 2020). The development of chronic infection is prevalent in infants infected by their mothers or usually before the age of 5 (WHO, 2020). Hepatitis $\mathrm{B}$ is also spread by percutaneous or mucosal exposure to infected blood and various body fluids including: saliva, menstrual, vaginal and seminal fluids. Hepatitis B infection may also occur by copulation. This happens when men that are not vaccinated against the infection have sex with men and heterosexual individuals with multiple sex partners or such men have contact with sex workers. When an adult is infected, it leads to chronic hepatitis in less than $5 \%$ of cases (WHO, 2020).The spread of the virus may also occur through the reuse of needles and syringes in the health care environment or among people who inject drugs into themselves. Apart from these, infections can also occur during medical, dental and surgical procedures including tattooing through use of sharp objects such as razors contaminated with infected blood (WHO, 2018).

It is important to note that most people do not experience any symptoms during the acute infection phase. Though, some people develop a severe illness with symptoms lasting for some weeks. These symptoms include abdominal pain, vomiting, dark urine, yellowing of the skin and eyes (jaundice), extreme fatigue and nausea (WHO, 2020). Only a small groups of persons with acute hepatitis B develop acute liver failure which eventually lead to death. While, in some people, chronic liver infection by the hepatitis $\mathrm{B}$ virus can later develop into cirrhosis or cancer of the liver (WHO, 2018). Hepatitis B infected children that are less than 6 years of age are the most likely to develop chronic infections (WHO, 2018).

A study by Anifowoshe et al., (2017) showed the distribution of $\mathrm{ABO} /$ Rhesus blood groups to be in the order $\mathrm{O}>\mathrm{A}>\mathrm{B}>$ $\mathrm{AB} \quad(52.93 \%, 22.77 \%, 20.64 \%$ and $3.66 \%)$ while the prevalence of $\mathrm{Rh}+$ was $94.90 \%$. Blood groups have been known to exist for centuries ever since man entertained the possibility of replacing blood loss through transfusion. They are responsible for determining the compatibility of blood in transfusion medicine and are also responsible for fetal loss in hemolytic disease affecting the fetus or newborn (Bowman, 1996).

Two of the most important classes of the blood group antigens are the $\mathrm{ABO}$ and Rhesus (Rh) systems, initially discovered in 1900 by Karl Landsteiner (Arggawal et al., 2018). Blood groups are hereditary as Mendelian codominant (Neil et al., 2003) traits and it is expected to appear in fairly comparable frequencies in the human race. A study by Genc (2017) carried 
out in Turkey, revealed that Blood group A, Rh positive was higher than other blood types in the chronic hepatitis B group $(44.3 \%)$ and in the control group (41.9\%), whereas blood types $\mathrm{O}, \mathrm{AB}$, and $\mathrm{B}$ were similar between cases with chronic hepatitis and controls $(p>0.05)$. HBV infection was moderately less frequent in subjects with $\mathrm{AB}$ positive.

Hepatitis is an urgent public health concern in Nigeria, one of the developing and Sub-Saharan African countries, with a rate of exposure as high as $75 \%$ (Musa et al., 2015). This situation is complicated by inadequate government funding and a lack of public awareness of the silent killer. This is further aided by general community misconceptions and sabotaging coverage there is (Cutts et al., 2013). According to WHO, only about $41 \%$ of the population had been vaccinated against HBV in 2015 (GAVI Alliance, 2014). Carrier rates between 9-39\% have been recorded in Nigeria (Emechebe et al., 2009).

Due to the high virulence, mortality, and suspected association between the blood-borne virus and the $\mathrm{ABO}$ blood group, it becomes essential to investigate the possible association between the $\mathrm{ABO} /$ Rhesus blood groups and HBV. Siransy et al., (2015) suggested that host factors are vital in the pathology of the infection. $\mathrm{ABO}$ and $\mathrm{Rh}$ blood groups play a vital role in blood transfusion safety and these two are thought to be associated with disease susceptibility (Liu et al., 2018). While there exists a body of data on the risk of contracting Hepatitis $\mathrm{B}$ through blood transfusions, the review of the virus, and others issues on $\mathrm{HBV}$, there is a scarcity of data showing the association between $\mathrm{HBV}$ and $\mathrm{ABO} / \mathrm{Rh}$ blood groups. This gap is what the study seeks to fill. Therefore, the study aims to assess the distribution of the $\mathrm{ABO} /$ Rhesus Blood Groups among HBV positive patients in Lagos State, Nigeria.

\section{METHODOLOGY}

Study Population and Data Collection

The study was conducted from April to November, 2019. The study subjects were Hepatitis B Virus infected patients accessing laboratory services at some health facilities in Lagos State. A written consent was obtained from each participant before recruitment into the study. A simple random sampling method was used to recruit known HBV positive patients into the study. The inclusion criteria were HBV positive patients who consented to the study. The exclusion criteria were patients who access the laboratories for services other than HBV related cases and HBV positive patients unwilling to participate in the study. Copies of structured questionnaires were used to obtain information on demographic data of the participants.

From each participant, venous blood was collected into a $4 \mathrm{~mL}$ EDTA vacutainer bottle and was inverted gently for the anticoagulant to mix properly with the blood. The blood was promptly transported in cold chain to the serology unit of the laboratory of the selected health facilities for processing. After collection, 50 microliters of the blood sample was taken out with a sterile Pasteur pipette and mixed with respective conventional blood grouping antisera. The blood group of the participants was then determined by the visible agglutination of the blood grouping antisera/blood complex.

\section{Sampling Size}

Systematic random sampling technique was used to determine the 162 participants, following sample size determination by Olayinka et al., (2016). For the sampling technique used, one respondent each was selected by the following steps: using the list of HBV patients, selecting a beginning number (using random number generator), selecting a sampling interval (calculating the sampling interval; the number of all patients, divided by the number of participants needed for the sample), and gathering a list of participants based on the interval number by repeatedly adding sampling interval.

\section{Data Analysis}

All statistical analyses were performed using the Statistical Package for the Social Sciences (SPSS) software, 20.0 version. Categorical variables expressed as frequencies and percentages were used to get the general description of the study respondents, sociodemographic characteristics and association of $\mathrm{ABO} / \mathrm{Rh}$ blood groups and $\mathrm{HBV}$.

\section{Results}

Socio-Demographic Distribution of the Study Population

One hundred and sixty-two (162) blood samples were collected from HBV positive patients. The mean age of the study population was 37.69 years (standard deviation of 10.65). The youngest age of the study participants was 20 years of age, while the oldest was 72 years old. There were $68(41.98 \%)$ females and $94(58.02 \%)$ male participants in the study (Tables 1 and 2). However, from the two tables (1 and 2), it is observed that male rhesus positive participants $(90=55.6 \%)$ were more than the female rhesus positive participants $(63=38.89 \%)$.

Table 1. Gender Distribution among ABO Blood Groups among HBV positive patients in Lagos

\begin{tabular}{lll}
\hline Blood Groups & & Gender \\
& MALE & FEMALE \\
\hline $\mathrm{A}+$ & 24 & 18 \\
$\mathrm{~B}+$ & 42 & 16 \\
$\mathrm{O}+$ & 42 & 28 \\
$\mathrm{O}-$ & 4 & 4 \\
$\mathrm{~A}-$ & 0 & 1 \\
$\mathrm{AB}+$ & 0 & 1 \\
\hline $\mathrm{MEAN} \pm \mathrm{SD}$ & $15 \pm 17.08$ & $11.33 \pm 1.06$
\end{tabular}


Table 2. Gender Distribution among Rhesus Blood Groups among HBV positive patients in Lagos

\begin{tabular}{lll}
\hline RHESUS STATUS & MALE & FEMALE \\
\hline NEGATIVE & $4(2.47 \%)$ & $5(3.09 \%)$ \\
POSITIVE & $90(55.6 \%)$ & $63(38.89 \%)$ \\
\hline MEAN \pm SD & $47 \pm 60.81$ & $34 \pm 41.01$
\end{tabular}

Table 3 shows the frequency of the ABO blood groups among the participants. Of the 162 participants, 26.5\% belong to blood group A, $24.7 \%$ belong to blood group $\mathrm{B}$ and $48.1 \%$ belong to blood group $\mathrm{O}$, while only $0.6 \%$ belong to $\mathrm{AB}$ blood group

Table 3. Frequency of HBV among ABO Blood Groups in Lagos

\begin{tabular}{lll}
\hline BLOOD GROUPS & FREQUENCY & PERCENTAGE (\%) \\
\hline A & 43 & 26.5 \\
B & 40 & 24.7 \\
O & 78 & 48.1 \\
AB & 1 & .6 \\
\hline Total & 162 & 100
\end{tabular}

Table 4 shows the frequency of Rhesus blood groups among the participants. One hundred and fifty three participants were rhesus positive, while only 9 participants were rhesus negative.

Table 4. Frequency of HBV among Rhesus Blood groups in Lagos

\begin{tabular}{lll} 
RHESUS STATUS & FREQUENCY & PERCENTAGE (\%) \\
\hline NEGATIVE & 9 & 5.6 \\
POSITIVE & 153 & 94.4 \\
& & \\
\hline Total & 162 & 100
\end{tabular}

\section{DISCUSSION}

The prevalence of HBV infection varies from country to country. Before now, it has been reported that the overall prevalence of HBV infection in Nigeria is $12.2 \%$ (Olayinka et al., 2016). In this study, the distribution of $\mathrm{ABO} / \mathrm{Rh}$ blood types in patients with HBV infection $(n=162)$ were compared and the prevalence of the blood groups are in the order, $\mathrm{O}>\mathrm{A}>\mathrm{B}>\mathrm{AB}$ (48.1\%, 26.5\%, 24.7\% and $0.6 \%$ respectively). These results could be because the gene for type $\mathrm{O}$ is 'recessive'. For instance, if you have one allele for $\mathrm{O}$ and an allele for $\mathrm{A}$, the individual will end up with A antigens on the cell membranes, and the same applies for B. In order to be group O, a person needs to inherit $\mathrm{O}$ alleles from both parents. Notwithstanding, group $\mathrm{O}$ is still more common simply because it is the ancestral blood genotype lacking antigens unlike the blood groups A, B and $\mathrm{AB}$ with antigens. $\mathrm{ABO}$ and $\mathrm{Rh}$ blood group distribution rates in this study therefore correlated with the systematic review done by Anifowoshe et al., (2017), where they observed $94.90 \% \mathrm{Rh}+$ prevalence. They also found the prevalence of the blood groups in the order, $\mathrm{O}>\mathrm{A}>\mathrm{B}>\mathrm{AB}(52.93 \%, 22.77 \%$,
$20.64 \%$ and $3.66 \%$ respectively). This study has revealed that blood group O participants had the highest prevalence (48.1\%) of HBV than the other blood groups. As observed in different studies on the association of Hepatitis $\mathrm{B}, \mathrm{ABO}$ blood groups and rhesus (Rh) factor by Siransy et al., (2015) and Shakeel et al., (2018), in which $49.74 \%$ and $38.7 \%$ were reported, respectively. However, a study by Genc, (2017) showed a deviation from what was obtained in this study, as a higher prevalence $(50 \%)$ was found among blood group A participants that are HBV positive.

Also, in this study, there was a higher prevalence (94.4\%) of HBV among Rhesus positive patients, which shows similar results with the studies carried out by Shakeel et al., (2018) in Abidjan where a $91.32 \%$ prevalence of HBV was reported. Also, Siransy et al., (2015) reported $97 \%$ of HBV prevalence among the patients sampled.

Unprotected sex in marriage is known to be a major means of transmission of HBV, which might escalate the likelihood of exposure and transmission of HBV. In a study among students, married students had a higher prevalence of HBsAg compared 
with single students, suggesting the role of sexual transmission of HBV (Bhattarai et al., 2014).

\section{CONCLUSION AND RECOMMENDATIONS}

The study has shown a high prevalence of blood group $\mathrm{O}$ (48.1\%) and Rhesus positivity (94.4\%) among HBV patients accessing laboratory services in some health facilities in Lagos State. It was also shown that participants with blood group $\mathrm{O}$ were at higher risk of $\mathrm{HBV}$ infection compared with group $\mathrm{AB}$. Also, Rh-D-positive participants were at higher risk of HBV infection than Rh-D-negative participants. The associations between $\mathrm{ABO} / \mathrm{Rh}$ blood groups and $\mathrm{HBV}$ infection were similar in subgroup analysis. Awareness and prevention of HBV infection is of particular importance for individuals with blood group O. Therefore, the risk of HBV infection and blood safety should be taken into consideration in medical practice, particularly during blood transfusing with blood group $\mathrm{O}$.

Following the findings from this study, it is recommended that more studies should be carried out in different parts of the country on common risk factors and sex/marital status of participants to allow for a more robust data. There should be more public awareness of HBV and the risk factors, so as to reduce the high prevalence in Nigeria.

\section{REFERENCES}

Aggarwal T., Singh D., Sharna B., Siddiqui S. S., Agarwal S. (2018). Association of ABO and Rh blood groups with Type 2 Diabetes mellitus in Muzaffarnagar city. Natl $J$ Physiol Pharmcol 8(2):167-170

Anifowoshe A. T., Owolodun O. A., Akinseye K. M., Iyiola O. A., Oyeyemi B. F. (2017). Gene frequencies of $\mathrm{ABO}$ and $\mathrm{Rh}$ blood groups in Nigeria: A review. The Egyptian Journal of Medical Human Genetics. 18: 205-210.

Bhattarai S., KC S., Pradhan P.M., Lama S., Rijal S. (2014). Hepatitis B vaccination status and needle-stick and sharpsrelated injuries among medical school students in Nepal: a cross-sectional study. BMC Res Notes 7: 774.

Bowman J. M. (1996). Hemolytic disease of the newborn. Vox Sanguinis, vol. 70, pp. 62-67.

Cutts F.T., Izurieta H.S., Rhoda D.A. (2013). Measuring coverage in $\mathrm{MNCH}$ : Design, implementation, and interpretation challenges associated with tracking vaccination coverage using household surveys. 128 (6):489-497. PLoS Med;10:e1001404.

https://www.ncbi.nlm.nih.gov/pmc/articles/PMC6420680

Emechebe G.O., Emodi I.J., Ikefuna A.N., Ilechukwu G.C., Igwe W.C., Ejiofor O.S. (2009). Hepatitis B virus infection in Nigeria - A review. Niger Med J; 50:18-22.
GAVI Alliance (2014). Country Tailored Approach for Nigeria 2014-2018. Available from: http://www.apps.who.int/immunization monitoring/globalsum mary/estimates?c=NGA. [Last accessed on 2014 May 27].

Genc O. (2017). Hepatitis B virus infection and $\mathrm{ABO} / \mathrm{Rh}$ blood groups. Int J Res Med Sci.Sep; 5(9):3782-3785.

Liu J., Zhang S., Liu M., Wang Q., Shen H., Zhang Y. (2018).Distribution of $\mathrm{ABO} / \mathrm{Rh}$ blood groups and their association with hepatitis B virus infection in 3.8 million Chinese adults: A population-based cross-sectional study. Journal of Viral Hepatitis. NCBI.PubMed. 25(4):401-411. doi: 10.1111/jvh.12829.

Musa B.M., Bussell S., Borodo M.M., Samaila A.A, Femi O.L. (2015). Prevalence of hepatitis B virus infection in Nigeria, 2000-2013: A systematic review and meta-analysis. Nigerian Journal of Clinical Practice, 18 (2):162-72.

https://www.ncbi.nlm.nih.gov/pubmed/25665986

Neil S. J., Magre S., McKnight A., Weiss R.A. (2003). A-B-O blood groups and HIV-1 infection. Antiviral Therapy, vol. 8, abstract 134 .

Olayinka A. T., Oyemakinde A., Balogun M. S., Ajudua A., Nguku P., Aderinola M., Egwuenu-Oladejo A., Ajisegiri S. W., Sha'aibu S., Musa B. O. P., Gidado S., Nasidi A. (2016). Seroprevalence of Hepatitis B Infection in Nigeria: A National Survey. Am. J. Trop. Med. Hyg., 95(4), pp. 902-907. doi:10.4269/ajtmh.15-0874.

Pirtle E.C., Beran, G.W. (1991). Virus Survival in the Environment. Rev. Sci. Tech. Off. Int. Epiz., 10(3):733-748.

Shakeel H. A., Maqsood H., Ali B., Khan A. R. (2018). Association of chronic viral hepatitis with $\mathrm{ABO}$ blood groups and rhesus (Rh) factor. Int J Res Med Sci. 6(4):1114-1118.

Siransy L.K., Nanga Z. Y., Zaba F. S., Tufa N. Y., Dasse S. R. (2015). ABO/Rh Blood Groups and Risk of HIV Infection and Hepatitis B among Blood Donors of Abidjan, Côte D'ivoire. European Journal of Microbiology and Immunology 5 (2015) 3, pp. 205-209. DOI: 10.1556/1886.2015.00029.

World Health Organization (2018). Hepatitis B. Available from: $\quad$ https://www.who.int/news-room/factsheets/detail/hepatitis-b. Last accessed on $18^{\text {th }}$ July, 2018.

World Health Organization (2018). Hepatitis B. Available from: $\quad$ https://www.who.int/news-room/factsheets/detail/hepatitis-b Accessed 29th August, 2020. 